\title{
Community participation in urban renewal projects: experiences and challenges of the case of Johannesburg, South Africa
}

\author{
W. Didibhuku Thwala \\ Department of Construction Management and Quantity Surveying, \\ University of Johannesburg, South Africa
}

\begin{abstract}
Urban renewal and inner city regeneration have become serious issues for the South African government which has invested in several structures to stem the tide of decline in its nine major cities. Commitment to alleviation of poverty has become very high on the government agenda and will stay one of the focal points of government. This is motivated by the fact that currently around $24 \%$ of the population lives on less than $\$ 1$ a day, below the poverty line defined by the World Bank. The Central Government has made numerous public commitments to development, a part of it concerning extensive infrastructure investment and service delivery. Communities are supposed to participate fully in the planning and implementation of urban renewal projects. Participation is a process through which stakeholders influence and share control over development initiatives, and the decisions and resources which affect them. Participation may be a means or an end, but in reality it is usually both. Involving people in order to increase awareness, empower, build capacity, or expand rights and duties may be an end in itself, but it may also function as an instrumental means for accomplishing a specific task. Similarly, working with people to accomplish a specific task may enable them to expand their confidence and ability to address other issues in their lives. Community participation should be aimed at empowering people by ensuring that skills are developed and that employment opportunities are created. The paper will firstly explore the concept of community participation. The paper will then look at some past experiences in relation to community participation in urban renewal projects. Furthermore the paper will outline the challenges and problems of community participation in urban renewal projects in Johannesburg. Finally the paper closes with some recommendations for the future.
\end{abstract}

Keywords: community participation, urban renewal, poverty, unemployment. 


\section{Introduction}

In South Africa, the levels of unemployment and poverty are extremely high and two of South Africa's most pressing problems. The levels of unemployment have been rising steadily over the years. The level of unemployment was 7\% in 1980, $18 \%$ in 1991 (McCutcheon [11,13]) and 28\% in 2003 (Statistics South Africa [17]). Commitment to alleviation of poverty has become very high on the government agenda and will stay one of the focal points of government. This is motivated by the fact that, currently around $24 \%$ of the population lives on less than $\$ 1$ a day, below the poverty line defined by the World Bank [19]. In addition to high levels of unemployment, there is also a widely acknowledged need for housing and municipal infrastructure (water supply, sewerage, streets, stormwater drainage, electricity, refuse collection). But most importantly, it is crucial to realise that there is a great need for physical infrastructure in both urban and rural areas. In addition there is a lack of capacity and skills at institutional, community and individual levels. This problem of infrastructure backlog is aggravated by the apparent lack of capacity and skills at institutional, community and individual levels. According to the World Bank [19] infrastructure can deliver major benefits in economic growth, poverty alleviation, and environmental sustainability - but only when it provides services that respond to effective demand and does so efficiently.

According to Thwala [18] over the past 25 years several projects have been initiated in South Africa to counter unemployment and poverty. It is envisaged that there will be others in the future. From a theoretical perspective supported by experience elsewhere in Africa, there are reasons for considering that properly formulated employment creation programmes based on the use of employmentintensive methods could be established to construct and maintain the required physical infrastructure, thus creating employment, skills and institutional capacities. The Urban Renewal Infrastructure Projects have the potential to redress this problem of disportionately high unemployment levels in South Africa and also to correct the skill deficits in disadvantaged communities. Among other things, these may be achieved through an efficient institutional set up, effective community participation, and construction technology that is pragmatic and innovative in nature.

The paper will firstly explore the concept of community participation. The paper will then look at some past experiences in relation to community participation in urban renewal projects. Furthermore the paper will outline the challenges and problems of community participation in urban renewal projects in Johannesburg. Finally the paper closes with some recommendations for the future.

\section{Community participation in urban renewal projects}

The World Bank [19] defines "participation is a process through which stakeholders' influence and share control over development initiatives, and the decisions and resources which affect them". The concept of community 
participation originated about 40 years ago from the community development movement of the late colonial era in parts of Africa and Asia. To colonial administrators, community development was a means of improving local welfare, training people in local administration and extending government control through local self-help activities (McCommon et al. [10]). However, during this era, the policy failed to achieve many of its aims primarily due to the bureaucratic top-down approach adopted by the colonial administrations (McCommon et al. [10]). Out of these experiences various approaches were developed that have been more successful and have gained broad support from all the major players in the development field (Abbott [1]).

Community participation generally is more successful when the community takes over much of the responsibility than when higher level public agencies attempt to assess consumer preferences through surveys or meetings. In order for community participation to work, projects must include special components addressing it. Villagers can be recruited to help in all phases of designing, implementing, maintaining, supervising, and evaluating new water supply and sanitation systems, but only if the time, effort and money is spent to do it right. Special attention must be paid to the development of local committees and governance structures that can adequately oversee local participation.

The direction and execution of development projects rather than merely receive a share of project benefits. The objectives of Community Participation as an active process are:

- empowerment;

- building beneficiary capacity;

- increasing project effectiveness;

- improving project efficiency; and

- project cost sharing.

The framework identifies four levels of intensity of participation, namely:

- information sharing;

- consultation;

- decision making; and

- initiating action.

This framework has been largely accepted by development agencies worldwide. However, a criticism of the model is that it is "project based" and does not include the full spectrum of Community Participation approaches. As such, the framework can be defined in planning terms as "means" orientated (Abbott [1]). The "means" approach views community participation as a form of mobilisation to achieve a specific, generally project related goal (Moser $[14,15]$ ). The alternative paradigm is the "ends" approach. This approach views community participation as a process whereby control over resources and regulative institutions by groups previously excluded from such control is increased, namely:

- the legitimacy of the authorities;

- the nature of development. 
In other words, situations in which the legitimacy of the authorities is in question will result in projects where participation is identified as an "end". Situations in which the development of services and housing is the main objective and require meaningful participation at a grassroots level are more likely to adopt the "means" approach. It is also possible that a situation will require a combination of the two approaches; such as in South Africa prior to the democratic elections in 1994. The government was not seen as legitimate by the majority of the population, however the provision of services and housing were key issues to be addressed; (since South Africa now has a legitimate national government it is now moving towards a means approach, but this is still complex at community level).

\section{Urban renewal infrastructure programmes in Johannesburg, South Africa: experiences, problems and prospects}

Urban renewal and inner city regeneration have become serious for the South African government which has invested in several structures to stem the tide of decline in its nine major cities. One of the projects is the Alexandra Urban Renewal project. The Alexandra Township was established in 1912 and is close to the centre of Johannesburg. It covers an area of over 800 hectares and its infrastructure was designed for a population of about 70,000. Current population estimates vary widely and have been put at figures ranging from 180,000 to 750,000. There are estimated 34,000 shacks of which approximately 7,000 are located in "backyards" (Gauteng Provincial Government [7]). The significant, unplanned population has overloaded the infrastructure such that water pressures are low and sewers frequently block and overflow. Maintenance of such systems is very difficult because the high densities and congested nature of the backyard shack development makes access for maintenance very difficult or impossible in places.

At the official opening of Parliament in February 2001, the State President announced a seven-year plan to redevelop Greater Alexandra in Johannesburg. The estimated budget for the Alexandra Renewal Project is R1, 3 billion over 7 years (Gauteng Provincial Government [7]). The Project is one of the eight original nodes forming part of the Government Integrated Sustainable Rural Development and Urban Renewal Programmes. These programmes are one of the main vehicles through which the Government is implementing its objectives of sustainable development and poverty alleviation. The projects are suppose to be labour-intensive in their nature so that more people can be employed and at the same time building new infrastructure for the community.

The Johannesburg Alexandra Renewal Project seeks to fundamentally upgrade living conditions and human development potential within Alexandra by:

- Substantially improving livelihoods within Alexandra and wider regional economy

- Creating a healthy and clean living environment 
- $\quad$ Providing services at an affordable and sustainable level

- Reducing levels of crime and violence

- Upgrading existing housing environments and creating additional affordable housing opportunities and

- Dedensification to appropriate land.

The following are the problems that hinder community participation in the Johannesburg Urban Renewal Projects which must be avoided in order for future projects to be successful in South Africa:

- There has been a lack of clear objectives linking the short and long-term visions of the programme.

- There were no pilot projects with extensive training programmes or lead-in time to allow for proper planning at a national scale. This should have allowed sufficient time to develop the necessary technology, establish training programmes and develop both the institutional and the individual capacities.

- The project has seldom been scaled to the magnitude of national manpower needs. Very often they have been introduced in an unsystematic and fragmentary style. This often led to technical hastiness, which was compounded by incompetence and inappropriate technology selection.

- There have been organisational infirmities and inappropriate administrative arrangements.

- There has been an imbalance between centralisation for higher level coordination and decentralisation for local decision-making and execution of works.

- Inadequate post-project maintenance arrangements often undermined the efficacy of the projects. This is largely attributed to the failure to ensure there would be an authority with a sufficient stake in the projects and in their continuing effectiveness (that is lack of community participation and ineffective local government).

- The projects have been over ambitious. This was a result of the lack of appreciation of the time it takes to build the necessary individual and institutional capacities at various levels.

- There has been a lack of clearly defined and executed training programmes that link medium to a long-term development plan.

- Individual skills were not improved. Training, where present, was not particularly appropriate or focussed and has not shown it to be carried through into post-project employment.

\section{Lessons and recommendations from the Johannesburg urban renewal projects}

One of the most important contributions of the Johannesburg Urban Renewal Project is that it resulted in an improved awareness of community participation 
issues and a better understanding of the mechanisms for achieving successful and sustainable projects. A number of key components had been identified in the research as important for the successful implementation of Urban Renewal programmes. There is a need for:

- $\quad$ Targeting the poor;

- Targeting women;

- Institutional training;

- Appropriate technology;

- Community participation;

- Community management; and

- Cost recovery.

Much of the success in the Urban Renewal Projects was achieved by using appropriate technologies and community-based approaches to projects. The conventional approach to infrastructural development adopted from urbanised, western, developed countries was found to be unsuitable because it was overly centralised and did not reflect local traditions and the needs for community participation.

The Johannesburg Urban Renewal experience found that one of the main issues relating to project sustainability is the management of the projects after completion, and not just involvement (or participation) in construction. As an attempt to articulate the responsibilities and management requirements necessary to promote local management of projects, the community management approach was developed. In practice, and for a variety of reasons, planning cannot be left totally to officials, specialists, administrators or experts. Some form of participation in planning is essential (Atkinson [2]). Development is not about the delivery of goods to a passive community, it is about active involvement and growing empowerment. Development is satisfying basic needs such as housing, water, health care, jobs and recreation in a way that changes economic, social and power relations (SANCO). Community participation has proved to be a success in a number of countries such as in Kenya, Botswana and Ghana where community participation was promoted in roads constructing, stormwater drainage, etc (McCutcheon [11,13]). In Tegucigalpa (the capital of Honduras) the community is involved in planning to meet their own needs and then take on management function which, ensures that the neighbourhood has safe water at a price they can afford (Choguill [3]). Therefore community participation in South Africa would also play a major role in alleviating the enormous lack of services such as sustainable clean water to rural communities.

It is argued that conventional services have not been or cannot be extended to the poor, as quickly as required. Therefore communities will have to organize to meet their own needs (Crook [5]). If participation is pursued there will be greater possibilities for self-reliance, which will lead to self-perpetuation of initiating projects. In addition, participation means services can be provided at a lower cost (Crook [5]). Therefore community participation should be promoted, especially for poor communities who have nothing to offer but their labour. According to Citicon [?] experience has taught us that decisions arrived at in boardrooms and 
applied at grassroots level are not usually received positively by target communities.

Some of these problems in Urban Renewal Projects in South Africa might be avoided by a careful approach to community participation. The validity of claims to be representative must be tested as early as possible. All interest groups in the community should be identified and consulted. Holding public meetings or advertising in newspapers may do this. Publicity material about a proposed programme can be distributed at public meetings. It should not be assumed that spokespeople at public meetings represent the majority or all of the community. Spokespeople may also say what they think outsiders want to hear in order to further their own positions or to be polite.

What must be realised is that in practice, planners may find that they play both roles interchangeably, depending on where they are in the planning process. Linking learning situations to the planning processes is one way in which one can ensure that what people learn is relevant to their situation and to ensure that what is learnt is applied and reflected upon as something that can be adapted or re-applied. Friedmann [6] believes that social learning approaches are appropriate to community self-empowerment since they require substantial departure from traditional planning practice which is typically imposed from above rather than generated within the community of the disempowered themselves. This has been evident in the kind of planning practiced during apartheid.

\section{Conclusion}

Phillips et al. [16] assert that community participation is required for work to be done which is required by the community. Although a technology may be appropriate to the available funds and the social conditions and operating and maintenance capacity in the community, the community may reject it as inferior because it differs from that used in wealthier areas. The community should participate in assessment of its resources and subsequently in the choice of technology.

Communities are highly complex and not single cohesive units. In the absence of legitimate and effective local government, other representatives of the community have to be identified. It may be difficult to determine whether an individual or organisation is representative of the community. A community organisation which is unrepresentative can cause resentment and conflict which may curtail a programme. Alternatively a development committee may be formed. Problems may also arise if the leadership of organisations representing the community changes or if other organisations become more powerful during a programme.

\section{References}

[1] Abbott, J. 1991. "Community Participation in Development". University of the Witwatersrand Course Notes, Environmental Health Engineering. Department of Civil Engineering. Johannesburg. 
[2] Atkinson, D. 1992. Let the People Decide: Public Participation in Urban Planning. Centre for Development Studies, University of the Western Cape.

[3] Choguill, C.L. 1994. Crisis, Chaos, Crunch? Planning for Urban Growth in Developing World, Urban Studies. Vol. 31, No.6.

[4] Coukis, B. et al. (1983) Labour-Based Construction Programmes - A Practical Guide for Planning and Management. Oxford: Oxford University Press for the World Bank.

[5] Crook, C. 1991. Government and Participation: Institutional development, decentralisation and democracy in the Third world, Chr. Michelsen Institute, Department of Social Science and Development.

[6] Friedmann, J. 1993. Towards a NonEuclidian Mode of Planning. American Planning Association Journal. Autumn. Vol. 54. No.4. pp. 482 -485 .

[7] Gauteng Provincial Government (2004) Alexandra Project: Review Summit 2004. Johannesburg: Gauteng Provincial Government.

[8] Jara, R.A. (1971) Labour Mobilisation and Economic Development: The Moroccan Experience. Ann Arbour, Center for Economic Development, April.

[9] Kalbermatten, J.M. and Middleton, R. N. 1992. Future Directions in Water Supply and Waste Disposal. Washington DC: Kalbermatten and Associates.

[10] McCommon, C. et al. 1993. Community Management of Rural Water Supply and Sanitation Services; Water and sanitation for Health (WASH) Technical Report No. 67. Washington DC: United States Agency for International Aid (USAID).

[11] McCutcheon, R.T. (1995) Employment Creation in Public Works: Labour-Intensive Construction in Sub-Saharan Africa: The Implications for South Africa. Habitat International, Vol. 19, No. 3 pp. 331-355.

[12] McCutcheon, R.T. and Marshall, J. (1998) Institution, Organisation and Management for large-scale, employment-intensive road construction and maintenance programmes. Construction and Development Series, Number 15, Development Bank of Southern Africa Paper No. 130, February.

[13] McCutcheon, R.T. (2001) Employment Generation in Public Works: Recent South African Experience. Construction, Management and Economics Journal.

[14] Moser, C. 1983. Evaluating Community Participation in Urban Development Projects. Proceedings of a Workshop held at the Development Planning Unit Barlett School of Architecture and Planning. London. University College of London.

[15] Moser, C.O. Community Participation in Urban Projects in the Third World, Progress in Planning, Oxford : Pergamon Press, Vol. 32, 1989, pp. 71-133.

[16] Phillips, S.D. et al. 1992. Employment Creation, Poverty Alleviation and the Provision of Infrastructure. Urban Forum. Vol.3, No.2. p.18. 
[17] Statistics South Africa (2003) Labour Force Survey for March 2003. Statistics South Africa, Pretoria, $23^{\text {rd }}$ September.

[18] Thwala, W.D. (2001). A Critical Evaluation of Large-Scale Development Projects and Programmes in South Africa 1980-1994._Unpublished Msc Thesis, School of Civil and Environment Engineering, University of the Witwatersrand, Johannesburg.

[19] World Bank (1994). World Development Report 1994. World Bank, Washington. 